NBER WORKING PAPER SERIES

\title{
DEBT INTO GROWTH: \\ HOW SOVEREIGN DEBT ACCELERATED THE FIRST INDUSTRIAL REVOLUTION
}

\author{
Jaume Ventura \\ Hans-Joachim Voth \\ Working Paper 21280 \\ http://www.nber.org/papers/w21280
NATIONAL BUREAU OF ECONOMIC RESEARCH
1050 Massachusetts Avenue
Cambridge, MA 02138
June 2015

\begin{abstract}
Ventura acknowledges support from the Spanish Ministry of Science and Innovation (ECO2011-23197), the Generalitat de Catalunya (2014SGR-830 AGAUR), the Barcelona GSE Research Network, and the ERC (Advanced Grant FP7-249588-ABEP). Voth acknowledges support from the ERC (Advanced Grant FP7-230515), the University of Zurich, and the SNF (100018-156197). The views expressed herein are those of the authors and do not necessarily reflect the views of the National Bureau of Economic Research.
\end{abstract}

NBER working papers are circulated for discussion and comment purposes. They have not been peerreviewed or been subject to the review by the NBER Board of Directors that accompanies official NBER publications.

(C) 2015 by Jaume Ventura and Hans-Joachim Voth. All rights reserved. Short sections of text, not to exceed two paragraphs, may be quoted without explicit permission provided that full credit, including (c) notice, is given to the source. 
Debt into Growth: How Sovereign Debt Accelerated the First Industrial Revolution

Jaume Ventura and Hans-Joachim Voth

NBER Working Paper No. 21280

June 2015

JEL No. E22,E25,E62,H56,H60,N13,N23

\begin{abstract}
Why did the country that borrowed the most industrialize first? Earlier research has viewed the explosion of debt in 18th century Britain as either detrimental, or as neutral for economic growth. In this paper, we argue instead that Britain's borrowing boom was beneficial. The massive issuance of liquidly traded bonds allowed the nobility to switch out of low-return investments such as agricultural improvements. This switch lowered factor demand by old sectors and increased profits in new, rising ones such as textiles and iron. Because external financing contributed little to the Industrial Revolution, this boost in profits in new industries accelerated structural change, making Britain more industrial more quickly. The absence of an effective transfer of financial resources from old to new sectors also helps to explain why the Industrial Revolution led to massive social change - because the rich nobility did not lend to or invest in the revolutionizing industries, it failed to capture the high returns to capital in these sectors, leading to relative economic decline.
\end{abstract}

Jaume Ventura

CREI

Universitat Pompeu Fabra

Ramon Trias Fargas, 25-27

08005-Barcelona

SPAIN

and Barcelona GSE

and also NBER

jventura@crei.cat

Hans-Joachim Voth

University of Zurich

Department of Economics

Schönberggasse 1

CH-8001 Zurich

and CREI

voth@econ.uzh.ch 


\section{INTRODUCTION}

Over the course of a century, a country accumulates towering debts, mainly to finance foreign wars - it is fighting abroad in two years out of three. Could such a country transition from centuries of stagnation to sustained growth? Surprisingly, the answer is yes - the Industrial Revolution in Britain occurred under such circumstances. The Glorious Revolution of 1688 turned Britain into a credible borrower; subsequently, borrowing increased massively (North and Weingast 1989). From 1692 to 1815, Britain's debt rose from 5\% to over 200\% of GDP (Sussman and Yafeh 2006; Barro 1987). The funds raised were not used to finance productivityenhancing infrastructures, but instead to pay for overseas wars. During this period, Britain was at war for 76 years $-62 \%$ of the time. And yet, frequent wars and high debt accumulation coincided with a remarkable transformation of the economy. By the end of the period, Britain's productive capacity had grown by a factor of eight, allowing it to sustain a population that was four times larger and twice as rich. Having moved millions of people from the countryside to urban centers, it had become the "workshop of the world".

How could Britain industrialize while accumulating towering debts that financed mainly foreign wars? Earlier research concluded that debt accumulation in 18th century Britain was detrimental to industrialization since it reduced the savings available for private investment: "Government borrowing had another ... effect. Capital was deflected from private to public uses, and some of the developments of the industrial revolution were once more brought to a halt" (T.S. Ashton 1948). Williamson (1984) used a calibrated model of the British economy to show that this crowding-out effect might have slowed output growth by as much as half of the potential growth rate. But crowding-out should work through interest rates, and there is little evidence that they increased. ${ }^{1}$ Barro (1987) argued that debt accumulation had a neutral effect on industrialization since it raised total savings instead of reducing private investment. ${ }^{2}$ Note that both Williamson and Barro assume that the British economy possessed well-functioning credit markets. ${ }^{3}$ The key question is then how much private savings increased in anticipation of future taxes required to service the debt. Williamson's answer is 'not much' while Barro's view is 'one-to-one'.

In this paper, we argue instead that Britain's debt accumulation accelerated industrialization. We model the Industrial Revolution as the arrival of new, highproductivity technologies. ${ }^{4}$ Entrepreneurs invest in these new industries because

\footnotetext{
${ }^{1}$ Research on interest rates and the yield on private assets has found few effects of sovereign borrowing. See Mirowski (1981); Clark (2001); Quinn (2001); Sussman and Yafeh (2004). Only Heim and Mirowski (1987) found evidence that nominal interest rates were somewhat higher during the Revolutionary Wars with France, but even then they found that real yields were lower. ${ }^{2}$ Indeed, historians have noted the highly elastic supply of savings in 18th century Britain (Neal 1995).

${ }^{3}$ By this, we mean that they assume that no-arbitrage conditions generally held, and that interest rates on government bonds, for example, are informative of the tightness of private credit.

${ }^{4}$ This is in the spirit of Hansen and Prescott (2001).
} 
profit rates are high. Initially, entrepreneurs are relatively poor and own a small fraction of the economy's savings. The lion's share of capital is in the hands of the nobility. Earls and dukes invest in agriculture and traditional industries where profit rates are relatively low. Ideally, entrepreneurs would borrow massively from nobles; this would lead to faster growth and a more rapid structural transformation. Financial frictions make his impossible: the banking sector is small and relatively inefficient, and the stock market is hamstrung by government restrictions. Prejudice also plays a role, as the nobility shied away from money-making activities. As a result, entrepreneurs are forced to finance their investments out of reinvested profits; capital formation and industrialization are relatively slow.

In such a setting, sovereign debt accelerates structural change. Sovereign bonds are attractive to the nobility because they offer higher returns than investments in agriculture and traditional industries. Entrepreneurs, on the other hand, are not tempted to buy sovereign bonds because returns in the new industries are even higher. Therefore, sovereign debt reduces investments in agriculture and traditional industries. Reduced labor demand in traditional sectors in turn depresses wages economy-wide, raising profit rates for entrepreneurs. Since reinvested profits provide most of their financing, this raises investment in new industries. In combination, this will ensure that sovereign debt accelerates structural change and growth. In contrast to Williamson and Barro, we emphasize the role of frictions in private credit markets - before the 19th century, little external financing found its way into new industries, despite huge profit opportunities. As we describe in section II, throughout the Industrial Revolution private credit was limited, expensive, and it provided almost no resources to the most dynamic sectors of the economy.

Our model highlights two features whose importance has become more apparent in recent years - the key role of resource reallocation and of credit market frictions in development (Hsieh and Klenow 2009, Banerjee and Moll 2010 and Gancia and Zilibotti 2009). The effects of credit market frictions is surveyed in Banerjee and Duflo (2005) and highlighted in recent research by, inter alia, Banerjee and Duflo (2014) and Banerjee and Munshi (2005) . Our emphasis on credit market frictions in a context of uneven growth in different sectors is related to Song, Storesletten, and Zilibotti's (2011) recent work on China. By emphasizing resource reallocation and credit market frictions, our model offers a unified explanation for key macroeconomic aspects of the Industrial Revolution.

The first aspect is relatively slow growth at the start of the Industrial Revolution. One of the key insights from the last 30 years of research on the British economy after 1700 is that growth was relatively slow before 1850, with output per capita rising at a rate of $1 \%$ p.a. or less (Crafts and Harley 1992; Antras and Voth 2003). As in the seminal work by Crafts (1985), structural change is the key characteristic of the industrialization process in our approach - the shift out of agriculture and into industry. Our model offers one interpretation of why growth was not faster: 
slow capital formation slowed down structural change because it was limited by the self-financing ability of entrepreneurs.

A second aspect of the Industrial Revolution that our framework sheds light on is the social change engendered by the Industrial Revolution. Britain's nobility in 1700 held the vast majority of wealth and political power; by 1900, its relative position had declined markedly. The nobility did not invest directly in new technologies; it also did not lend to capitalists, either directly or through the financial system. Had the nobility been able to finance the new class of entrepreneurs in a competitive well-functioning credit market, it would have appropriated virtually all of the profit opportunities arising from the new technologies - and the Industrial Revolution would have generated little or no social change. ${ }^{5}$

A third aspect of the Industrial Revolution is limited gains in terms of living standards accruing to the working class. Real wages did not keep up with output growth during the core phase of the industrialization process (1770-1830); the wage share of national income fell sharply, while the share going to capital surged (Allen 2009). Our model offers an explanation for this puzzling feature, by showing how massive sovereign borrowing contributed to the divergence between productivity and wages. It is precisely the reduction of labor demand (because nobles switched from low-return investments to sovereign debt) that kept wages low and generated the entrepreneurial profits needed to finance industrialization.

We deliberately abstract from other aspects of the Industrial Revolution. First, we take technological change as given. While the aggregate productivity statistics do not show it, the eighteenth century saw many important inventions and innovations, from the use of steam power to advances in cotton spinning, weaving, and transport (Mokyr 1990). Nor do we seek to explain why these advances were first conceived or implemented in Britain (Allen 2009). Furthermore, we do not examine the role of new sources of energy (Wrigley 1990, Stokey 2001), nor of foreign trade (Crafts 1985, Crafts and Harley 2000, Temin 1997) or of improvements in transport (O'Rourke and Williamson 2005, Bogart 2009). Finally, we do not consider the impact of institutional improvements (North and Weingast 1989, Mokyr and Nye 2007). All these factors undoubtedly contributed to the Industrial Revolution in ways small or large. Here, we focus on the factors that determined how quickly technological change made itself felt in the economy at large.

The rest of the paper is organized as follows. Section II provides the historical background and context. It reviews the stylized facts of the Industrial Revolution and it also describes the main features of the British financial system. Section III presents our model and derives our analytical results. It also provides a very rough attempt at quantification. Section IV concludes.

\footnotetext{
${ }^{5}$ This depends on the relative bargaining powers of savers and investors in new technology. However, since the nobility was small, it is likely that it would have exerted substantial market power.
} 


\section{Historical Background}

In this section, we first briefly summarize key macroeconomic features of the British Industrial Revolution, as well as of the political context. In addition, we discuss the social and distributional consequences of the transition to self-sustaining growth, and we highlight the main features of the UK financial system.

2.1. War and the growth of debt in eighteenth-century England. The socalled Glorious Revolution in 1688 deposed James II from the throne. Parliament invited William of Orange to become monarch. The new constitutional settlement included major restrictions of the monarch's powers, and a much-expanded role for Parliament. Taxation required the parliamentary assent; the judicial powers of the king were severely curtailed (North and Weingast 1989).

At the time of the Glorious Revolution, Britain had only a small national debt. In the next 150 years, the total debt stock rose rapidly. Between 1692 and 1815, debt rose from $5 \%$ of GDP to more than 200\% (Barro 1987). The cost of numerous wars that followed the accession of the Hanoverian kings to the throne was largely responsible. Britain found itself at war for 81 years, or almost 2 out of every 3 . The expenditure on the armed forces was considerable, and constituted by far the single most important item of the government budget. A single ship of the line of the Royal Navy cost more than all the capital in the most expensive iron-works built at the time (Brewer 1990). In the period 1692-1815, spending on the Army, Navy and on ordinance was equivalent to $72 \%$ of total revenue. Once the debt service costs were added to this figure - due to the debts accumulated in wartime - there was hardly any money left for non-military spending.

Figure 2.1 shows the path of overall expenditure and of total debt. Shaded areas indicate wars. Dramatic spikes in total spending almost always coincided with major wars. Almost the entire rise in debt during the eighteenth century occurred while Britain was fighting abroad. Once peace was concluded, debt levels typically stabilized in nominal terms, and GDP growth reduced the debt burden over time. Peaking at over 200\% after the end of the Napoleonic Wars, debt eventually fell to $100 \%$ of GDP by the middle of the nineteenth century.

Due to frequent wars, borrowing needs were substantial. In addition, new financial instruments facilitated the growth in public debt. Prior to the eighteenth century, most borrowing by the English Crown was complex and created liquid assets. So-called tallies - notched wooden sticks denoting various amounts of taxes payable to the government - were used to borrow. In effect, tally rods acted like short-dated IOUs issued by the government, backed by a specific tax stream. While these could be resold, trading was typically highly illiquid, with discounts of more than half of face value. After numerous experiments, the British government granted privileges to several companies, in exchange for financing the public debt. The most important included the Bank of England, the New East India Company, and the South Sea Company. All of these received royal charters in exchange for taking on some 
Figure 2.1. Debt and Expenditure in the UK, 1692-1860

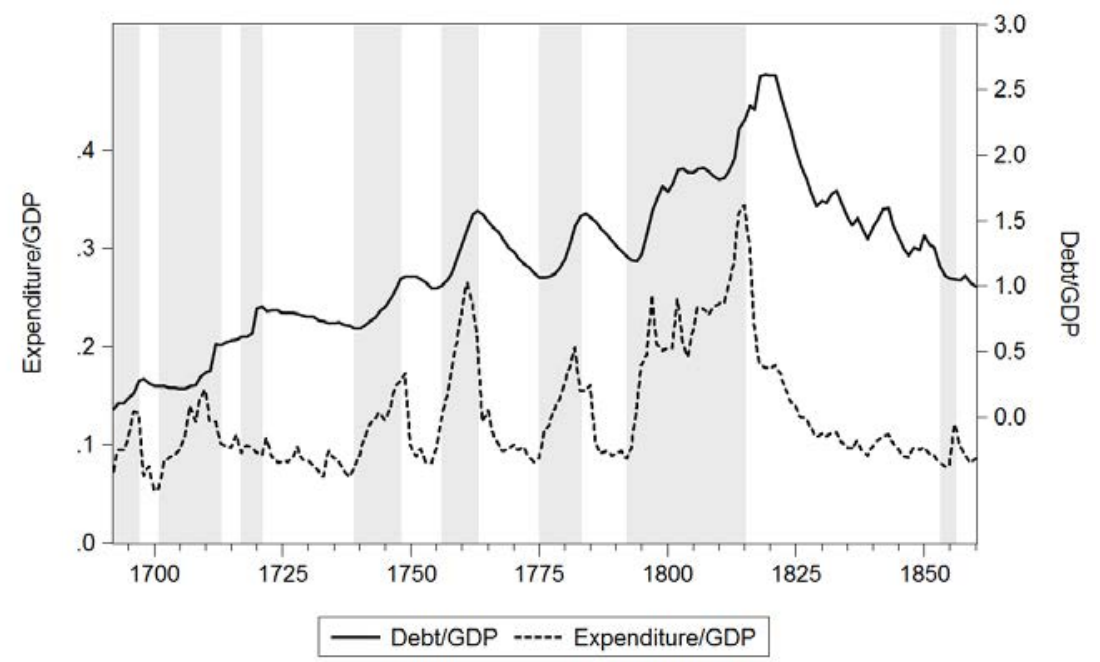

of the government's debts. In addition, government bonds were combined with a national lottery (Million Adventure). Life annuities were issued, as well as tontines. Short-term borrowing in case of war by the armed forces produced so-called army and navy bills, effectively short-dated promises to pay. The biggest experiment of all involved the South Sea Company, which offered to exchange all public debt in 1720 for shares. A similar exercise in 1719 had been attractive to both the government and the public, by improving the liquidity of outstanding debt. While the South Sea scheme ultimately failed, it demonstrated the attractions of liquid paper assets. The UK finally introduced consolidated annuities ("consols"), perpetual bonds with a relatively low interest rate (Dickson 1967). These were first issued in 1751. Originally carrying a yield of $3.5 \%$, they were eventually converted to $3 \%$ in 1757 (and to $2.75 \%$ in 1888). Consols were liquidly traded, and became a prime savings vehicle for the moneyed classes in the UK.

2.2. Britain's growth and industrial transformation. Growth during the classic period of the British Industrial Revolution (1760-1850) was slow by modern standards. Initially, output growth per capita was barely faster than during the pre-industrial period. ${ }^{6}$ After the middle of the 18th century, growth accelerated from around $1 \%$ p.a. to $2.5 \%$. At the same time, population increased rapidly, from 5.2 million to 19 million. Growth rates across sectors were highly unequal. Figure 2.2 shows annual GDP by sector. Agriculture expanded relatively slowly over the period 1700-1860, increasing total output by a factor of 2.8 - a slower rate of increase than that of population. ${ }^{7}$ Over the same period, real GDP in services increased 9-fold, and in industry, 14-fold (Broadberry et al. 2010) .

${ }^{6}$ Galor $(2005)$ gives a figure of $0.1 \%$ p.a. for the pre-industrial era, while the work of Crafts and Harley suggests rates of $0.2 \%$ p.a. in the years $1760-1800$.

${ }^{7}$ For the effects of population pressure on economic structure, cf. Crafts and Harley (1992). 


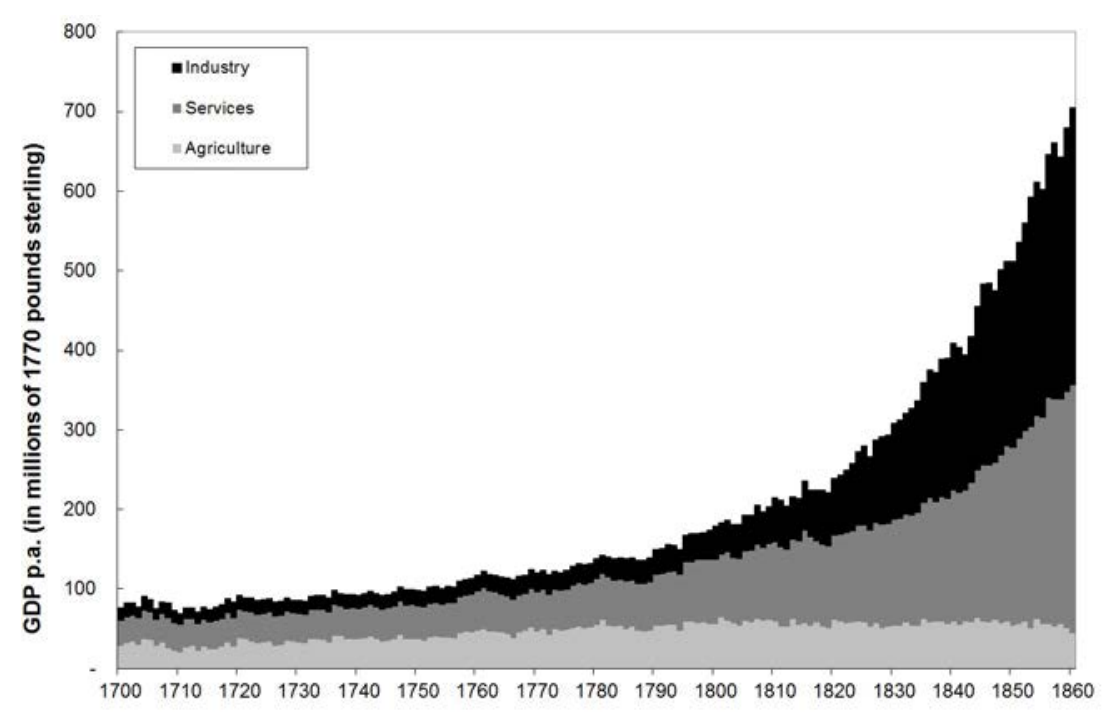

FIGURE 2.2. Growth of Output in Britain, 1700-1860

TFP growth remained below $1 \%$ p.a. until the 1830 s, if not longer. After 1760 , investment as a percentage of GDP probably increased from around $8 \%$ to over $12 \%$. Capital input in the economy grew slightly more rapidly than labor input, creating a small rise in capital intensity. Land in use also increased as more marginal areas were brought under the plough. Aggregate TFP growth was not high by the standards of later periods, but faster than before 1760. These findings are confirmed by studies using the productivity dual - factor returns did not increase rapidly overall. ${ }^{8}$ Table 1 summarizes the key facts:

TABle 1. Estimates of Productivity Growth in England, 1770-1860

\begin{tabular}{lrrrrr}
\hline & \multicolumn{5}{c}{ change in \% p.a. } \\
\cline { 2 - 6 } Antràs and Voth (2001) & $\mathbf{r}$ & $\mathbf{~ w}$ & $\mathbf{q}$ & $\mathbf{T F P}$ \\
\cline { 2 - 6 } 1770-1801 & -0.28 & 0.40 & 0.13 & 0.12 \\
$1801-1831$ & 0.83 & 0.34 & 0.20 & & 0.49 \\
$1831-1860$ & 0.74 & 0.56 & 0.11 & & 0.56 \\
& & & & & \\
Harley (1999) & $\mathbf{Y}$ & $\mathbf{K}$ & $\mathbf{L}$ & $\mathbf{T}$ & $\mathbf{T F P}$ \\
1760-1800 & & & & & \\
1801-1831 & 1.0 & 1.0 & 0.8 & 0.2 & 0.19 \\
1831-1860* & 1.9 & 1.7 & 1.4 & 0.4 & 0.50 \\
\hline & 2.5 & 2.0 & 1.4 & 0.6 & 1.00 \\
\hline
\end{tabular}

Sources: Antràs and Voth (2001), Harley (1999, p. 183).

Notes: $\mathrm{r}$ - rental rate of capital, w - real wage, $\mathrm{q}$ - rental cost of land

$\mathrm{Y}$ - output growth, $\mathrm{K}$ - capital, L - labour, T - land

Antràs and Voth (2001) use an elasticity of 0.35 for capital, 0.15 for land, and 0.5 for labour.

$\overline{{ }^{8} \text { Antras and Voth }}(2003)$. 
Wages increased relatively slowly between 1760 and 1860, by approx. 30\% (Feinstein 1998). The remuneration of labor thus failed to grow in line with output per capita. ${ }^{9}$ The same is true for land rents. Because rents and wages grew less rapidly than output, the share of capital in total factor payments increased (Table 2 ). The period 1770-1850 therefore saw a major increase in the capital share of output (Allen 2009), which rose from $18 \%$ to $45 \%$ in less than a century. Growth of the capital stock was only one reason for the rise in the capital share. Crafts (2005) estimates that capital deepening contributed approximately one third to total per capita output growth during the Industrial Revolution. The rate of return on capital in Britain also grew from $10 \%$ in 1770 to over $23 \%$ by 1860 .

TABLE 2. Factor shares in Britain, 1770-1860

\begin{tabular}{lccc}
\hline & $\mathbf{1 7 7 0}$ & $\mathbf{1 8 6 0}$ & Change 1770-1860 \\
\cline { 2 - 4 } Capital & $18 \%$ & $45 \%$ & $+27 \%$ \\
Labor & $60 \%$ & $47 \%$ & $-13 \%$ \\
Land & $22 \%$ & $8 \%$ & $-14 \%$ \\
\hline
\end{tabular}

The slow rate of output growth is remarkable not least because technological change was rapid. A "wave of gadgets" (TS Ashton) in the 1770s and 1780s created the foundations for new products and processes. The frequency of useful patents, as measured by their subsequent citation frequency, surged. Foreign trade statistics suggest that technological change was broad-based. ${ }^{10}$

These changes in factor shares also spelled social change. As income on capital increased, the relative importance of landed wealth declined. Slowly but steadily, Britain's nobility lost its position of paramount importance in the national wealth and income rankings (Rubinstein 1977).

Rapid structural change was the most outstanding feature of Britain's industrial transformation (Crafts 1985). While total population more than doubled, the absolute number of people employed in agriculture remained broadly constant. Thus, the share of Britons working in agriculture fell from 57 to 25 percent over a 150 year period. ${ }^{11}$ Compared to the 'European norm', Britain experienced an early and rapid shift from the primary to the secondary sector (Wrigley 1985).

2.3. The rise of new industries. While aggregate growth rates were low, some individual sectors grew rapidly. Cotton, and to a lesser extent, iron production, transportation, and machinery expanded rapidly, starting from a low base. Productivity in cotton production increased by $2.6 \%$ annually, shipping by $2.3 \%$, and worsteds and canals by 1.3 and $1.8 \%$ respectively over the period $1780-1860$. This implies that Britain became 8.8 times as productive in producing cotton goods, for

\footnotetext{
${ }^{9}$ More recent work by Clark (2005) suggests slightly faster growth, but still confirms the conclusion that output growth was markedly faster than wage growth.

${ }^{10}$ Cf. Temin (1997). The conclusion has been questioned by Crafts and Harley (2000).

${ }^{11}$ Crafts (1985).
} 


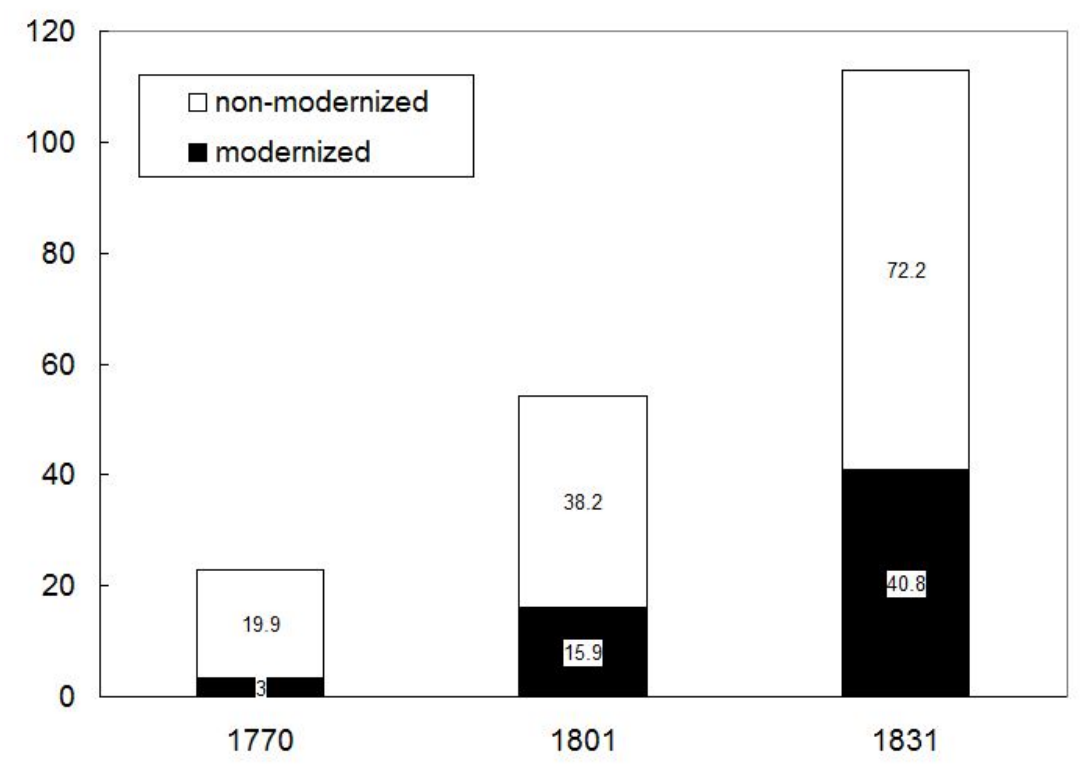

FiguRE 2.3. The growth of modernizing industrial sectors, 17701831 (value added in millions of pounds sterling p.a.)

example. Output in new sectors expanded even more, as more labor and capital were drawn in. Cotton production increased 42 -fold over the period.

As the new sectors grew, their share of the industrial sector increased - and the economy itself became increasingly industrialized. Figure 2.3 illustrates the growing importance of "modernizing" sectors. From $13 \%$ of industrial output, modernizing sectors grew to $36 \%$ by 1831 . In other words, by 1830 , more than one third of industrial output already came from the sectors that benefited the most from the new inventions of the industrial era, a share that only increased subsequently.

2.4. The UK financial system. While government debt surged after 1680, private credit intermediation remained remarkably underdeveloped. As Postan (1935) observed, "the reservoirs of savings were full enough, but conduits to connect them with the wheels of industry were few and meagre ... surprisingly little of [Britain's] wealth found its way into the new industrial enterprises ..." . In other words, the new, dynamic sectors of the economy - cotton manufacturing, iron production, coal mining, ceramics - were initially starved of capital. They largely financed themselves through retained profits and informal credit. Peer-to-peer lending dominated where credit was available at all - entrepreneurs were forced to turn to friends, family, and local owners of liquid funds to raise capital (McCraw 1997; Mokyr 1999). ${ }^{12}$

Private credit markets worked poorly for several reasons. The Bank of England was largely a conduit for government debt. Goldsmith banks were small and few

\footnotetext{
${ }^{12}$ In contrast to France, Britain had no system of public notaries who facilitated such transactions (Hoffman, Postel-Vinay, and Rosenthal 2000). Note that informal lending is still common today, both in the developing world and in countries with highly developed capital markets (Azam et al. 2001, Townsend 2005).
} 
in number, and only catered to a moneyed and landed elite. Merchant banks financed foreign trade. Almost no financial institutions attempted to provide funds for entrepreneurs. ${ }^{13}$ Banks were hamstrung by government regulations. The size of partnerships in England was limited to six, severely curtailing the size of banks. Usury laws limited (private) interest rates. This rule made lending on anything but the best collateral, and to the safest borrowers, unprofitable. Temin and Voth (2008) document how the usury law led to massive distortions in lending. In addition, loans could legally not be made for periods greater than six months. This made it hard for borrowers to use funds for illiquid investments. There was no central bank, charged with providing liquidity. Existing banks struggled under the threat of illiquidity, and many floundered because of it.

Nor could new firms easily raise equity on the stock market. As a result of the South Sea bubble, the government introduced tight restrictions on the founding of new joint stock companies in the form of the so-called "Bubble Act". The legislation required all new joint stock companies to have a royal charter. Effectively, until its repeal in the $19^{\text {th }}$ century, the Bubble Act closed the door on all forms of capital raising via the issuance of new equity (Harris 1994). In combination, private credit intermediation in Britain before the 1820 s worked poorly at best. On the whole, it failed to provide significant funding for new enterprises, which were mostly financed from retained earnings. Nothing attests more eloquently to the shortcomings of the UK financial system than the large gap between rates of return on capital invested in manufacturing on the one hand (Allen 2009 ), and the cost of borrowing on the other.

2.5. The market for land. Wealth in England was overwhelmingly held in the form of land. Lindert (1986) estimates that it accounted for $74 \%$ of total wealth in 1740. As late as 1875, this share was close to half. Most land was owned by the nobility and landed gentry. While land could in general be bought and sold, the extent of the land market was relatively limited. In the Middle Ages, outright ownership of land was only possible for the Crown. Gradually, England evolved two forms of ownership - freehold and leasehold. Freehold property can be transferred freely and entitles the owner to all rights. Leasehold comes in a bewildering range of types, from tenancy at will to leases for life and leases with large entry "fines" and low annual charges. All of these involved the eventual (possible) reversion of full ownership to the freehold owner.

In addition, many noble estates were structured in the form of perpetual trusts. This made it impossible for heirs to sell land outright, thus checking the tendency of some nobles to overspend, borrow on mortgage, and then have to sell the land to satisfy creditors. Only leases could be agreed for land held in perpetual trusts.

\footnotetext{
${ }^{13}$ Brunt (2006) argues that country banks acted like venture capital firms during the British Industrial Revolution. The cases he shows are suggestive, but it is doubtful that this represents an important part of business financing at the time. The analogy with venture capital firms is also strained, since the upside to the bank was severely limited - at no more than $5 \%$.
} 
This limited the extent to which land could become a widely-traded asset. As a result, almost no Englishmen other than members of the titled elite could aspire to freeholds. Nor could commoners freely add to land holdings due to a general scarcity of property available for outright purchase.

In one sense, however, the market for land in England was efficient. Leaseholders paid rent charges to the freeholder. These could be renegotiated with varying frequency. As Clark (2002) demonstrates, rent charges in general moved with the productivity of land.

2.6. Comparative rates of return. For our argument to hold, comparative rates of return on assets have to show a particular ordering. Rates of return on investment in agriculture have to be lower than on government debt; and government debt in turn has to pay less than equity investments available to capitalists, especially those in the new industries.

Landlords with money to invest in the land could either acquire more of it (as far as it was available), or use it in improvements such as drainage, liming and marling, as well as enclosure. Neither was more profitable than purchases of government bonds. Figure 2.4 shows the relative valuation of government bonds (consols) and of land, from 1795 to 1930. The y-axis measures "year's purchase", meaning the multiple of annual payments received by the owner. Until the 1890s, land traded at a higher multiple than government debt - the interest on the (liquidly traded) debt was markedly higher than the yield on land, which was not only hard to trade; administering it was also costly.

The implications were not lost on landowners. A few, large landholders such as the Duke of Marlborough had very large holdings of government debt as early as 1750 (Dickson 1967). The Earl of Shelburne, at the time of his death in 1751, held $99 \%$ of his wealth in government debt. Just one generation earlier, this would have been unthinkable. Especially newly rich members of the gentry did not commit a large share of their assets to land anymore:

"Once secure long-term paper assets were available which did not require active management by the owner there were very good reasons why a new man who wished to establish a landed dynasty should retain ... his fortune in such assets... as part of the longerterm endowment of the family. They yielded a much higher net income than that derived from land purchase."

The Prime Minister, Sir Robert Peel, advised that "every landowner ought to have as much property (as his estate) in consols or other securities..." (Habakkuk 1994).

Nonetheless, in the mid-eighteenth century, most of the landed elite was yet to move massively into consols and other government debt. Over the next hundred years, they did so. The period after 1750 saw an important reduction in investments in land and an increase of investments in government debt. As one large landowner explained to another in 1847, he was going to sell land and invest in government 


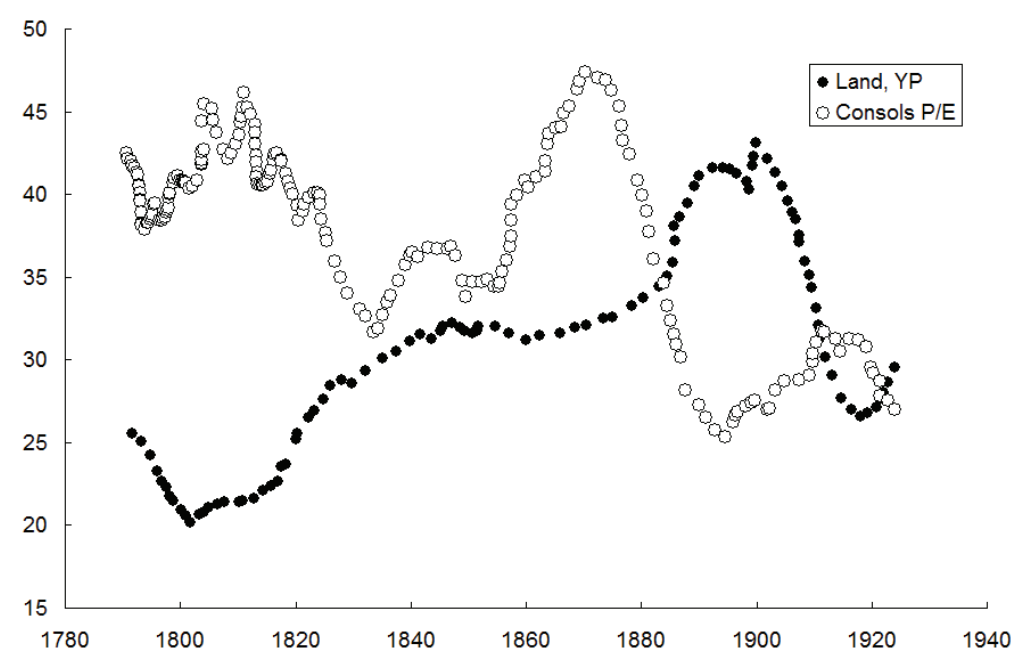

FiguRE 2.4. Relative valuation of government bonds and land

debt ". . . because I do not think it worth while to keep a security paying 2 per cent, when I can get an equally good one paying 5." Lord Monson put it simply: "What an infernal bore is landed property. No certain income can be reckoned upon. I hope your future wife will have consols..." (Thompson 1963). Indeed, by the $19^{\text {th }}$ century, an increasing number of peers was not just curtailing investment in land, but selling off large parts of their landholdings in a bid to diversify and increase their income (Habakkuk 1994). Similarly, as Jane Austen's novels make abundantly clear, members of the gentry in general held most of their wealth in government debt by the early 19th century (Copeland 1993).

Land improvements also made poor investments. For example, the Duke of Northumberland invested nearly $£ 1$ million between 1847 and 1878; only at the end of the period did this enormous expense yield a return of 2.5 percent - at a time when consols carried a yield of over 3 percent (Thompson 1963). Drainage only got under way on a large scale in the $19^{\text {th }}$ century. It required help through government loans to be profitable (Phillips 1989). Enclosure's profitability is controversial. While authors initially argued that potential profits were high (McCloskey 1972), later work has overwhelmingly concluded that economic gains were minor and costs tremendously high (Clark 1998; Allen 1999). Clark estimates that enclosure's average return after costs was a mere 0.6\% during the period 1600-1830; it was only after the 1750 s that it became profitable at all, in some parts of the country, because of rising agricultural rents. Figure 2.5 compares returns to land enclosure and on government debt over time. There is no decade when investments in land yielded a higher return than government bonds.

Importantly, net rent gains on enclosed land varied widely - Clark reports a range of -1 to $111 \%$ for individual estates, for enclosures after 1750. Because average gains were small and heterogeneity high, it is plausible that on many estates and for long 


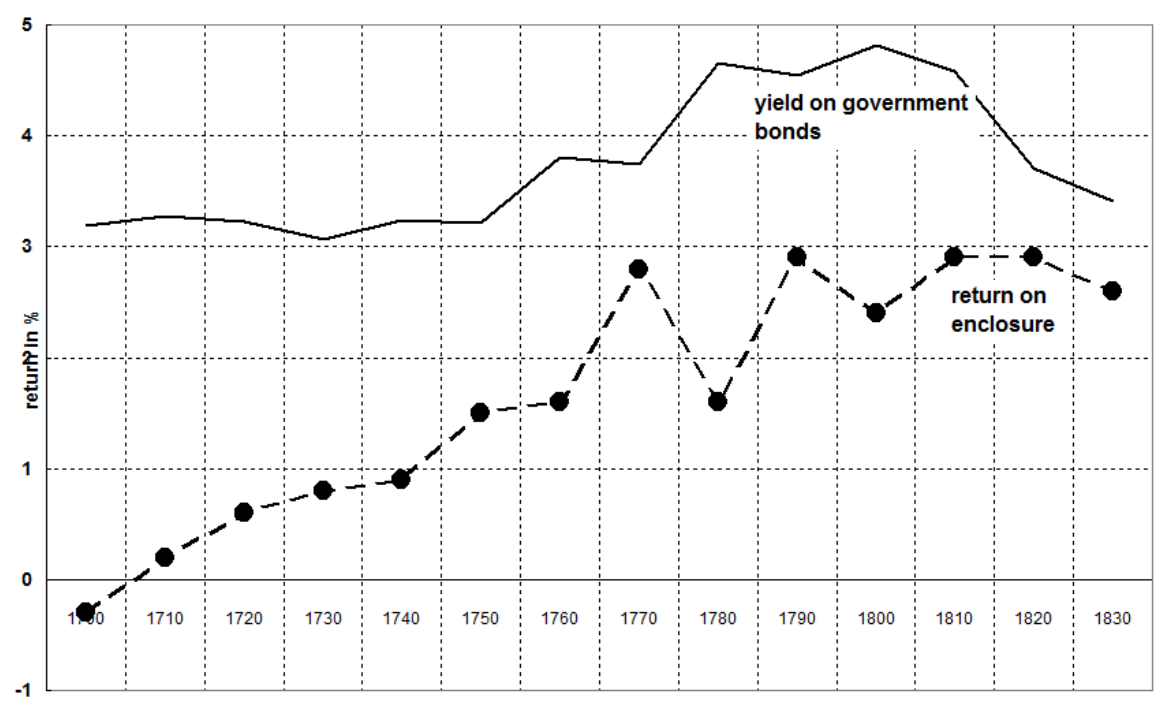

Figure 2.5. Yield on Government Bonds and Returns to Enclosure, 1692-1860

periods of time, there was little economic gain from investing money in enclosing the land. In other words, many landlords, faced with a choice between investing in improving their estates and investing in government bonds must have found the latter vastly more attractive. In addition to the high average return, they could hold an asset that yielded the same or more every year, was uncorrelated with the value of most of their property, and that could be traded liquidly.

Finally, for our argument to be valid, it has to be the case that government bonds offer returns that are lower than those attainable to investors in manufacturing. While evidence is sketchy, (Allen 2009 calculates the rate of return on capital invested in manufacturing, and finds rates in excess of $10 \%$, rising to $25 \%$ as the Industrial Revolution wore on. Anecdotal evidence strongly suggests that rates of return on capital in new industries were even higher.

2.7. Dynamic inefficiency. One simple criterion for dynamic inefficiency is that the return to capital is lower than the investment rate: $r_{t} K_{t} \leq I_{t}$ where $\mathrm{r}$ is the rate of return, $\mathrm{K}$ is the capital stock, and $\mathrm{I}$ is investment. In other words, if a country invests more than the return on capital, it could improve output by reducing investment - its investment exceeds Phelps' "Golden Rule" (Abel et al. 1989 ). We argue that this was the case in British agriculture before the surge of government debt issuance.

Returns to agriculture are composed of three elements - payments for labor used, for land, and for capital invested in agriculture. Good data before the Industrial Revolution is largely nonexistent. During the period 1770-1810, the agricultural capital stock increased by $£ 138$ million; over the same period, total income in the 


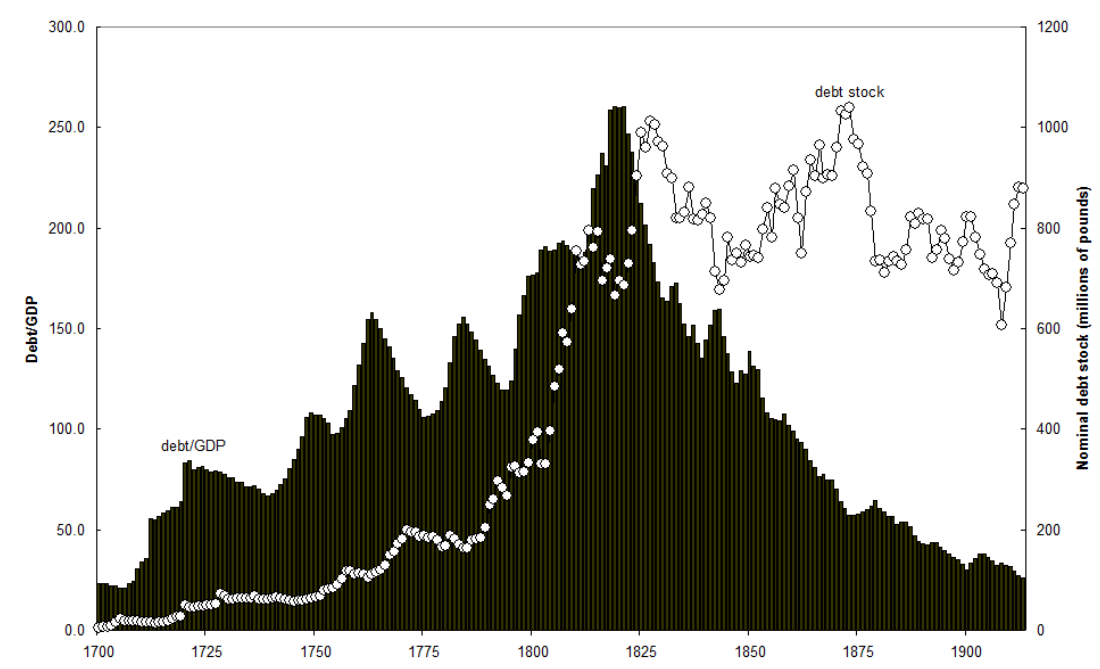

FiguRE 2.6. UK debt dynamics, 1700-1913

agricultural sector amounted to $£ 217$ million. The capital share in agriculture was probably around $20 \%$ (Crafts and Harley 2000), corresponding to $£ 43$ million. In other words, net investment in agriculture for a good part of the late 18th century was three times higher than the return to capital. ${ }^{14}$ This strongly suggests that dynamic inefficiency in agriculture was a real possibility. This must be all the more true for the period before 1750 , when few assets competed with capital investments in agriculture.

Interestingly, this pattern reversed in the early 19th century, when the new industries had reached a substantial size and urbanization was high. Growth accelerated as the high rates of productivity and output growth in the new sectors applied to an ever larger base. In parallel, over the period 1820-50, the UK capital in the agricultural sector probably generated returns of $£ 41$ million, while the agricultural capital stock declined, generating a surplus for consumption of $£ 78$ million. In other words, dynamic inefficiency was no longer a feature of the UK agricultural sector after 1815 - as we would expect if debt issuance was effective in draining the "swamp" of inefficient investment in agriculture.

An alternative criterion for dynamic inefficiency is that the return on government debt be lower than the rate of output growth. To show this, we calculate holdingperiod returns for bond holders, combining interest received with changes in the value of bonds. In 43 out of 160 years - $27 \%$ of the total - the return to bonds was actually less than the rate of growth.

Figure 2.6 shows how both the absolute stock of debt and debt/GDP ratio evolved over time. In the 18th century, debt surged in wartime. In peacetime,

\footnotetext{
${ }^{14}$ If we use the alternative, higher capital shares in Stokey (2001) for the economy as a whole, we still find that investment was greater than capital income.
} 
its level was essentially flat, or falling slightly at best; but debt/GDP ratios declined rapidly as growth eroded the relative weight of previous borrowing. The same mechanism was at work after 1815. In 1815, after the end of the Napoleonic Wars, Britain's debt amounted to $£ 792$ million ; in 1914, to $£ 843$ million, some $6 \%$ higher. At the same time, the debt/GDP ratio declined to $1 / 10$ th of its former level, from $226 \%$ to $25 \%$. Britain's 18th century borrowings were never repaid; its massive debts simply dwindled into insignificance as a result of rapid economic growth.

\section{DebT Into GRowTh: Understanding THE MECHANISM}

Here, we present our argument in four steps. First, we present our basic setup and describe the pre-industrial steady state. Second, we model the Industrial Revolution as a process of structural change and show how the absence of an effective private credit market allows us to account for some of its key historical features. Third, we use the model to study the effects of sovereign debt and the channels through which it affects structural change and economic growth. Fourth, we simulate the model to gain insight intor the quantitative importance of the mechanism that we propose.

3.1. The pre-industrial society. Consider an economy with a single or composite good that is produced with three factors, land, capital and labor. The production technology can be represented as follows:

$$
F\left(l_{t}, k_{t}, n_{t}\right)=l_{t}^{\lambda} \cdot k_{t}^{\alpha} \cdot n_{t}^{1-\lambda-\alpha}
$$

where $l_{t}, k_{t}$ and $n_{t}$ are land, capital and labor; and $\lambda>0, \alpha>0$ and $\lambda+\alpha<1$. Land and labor exist in fixed supply and we normalize their sizes to one, i.e. $l_{t}=n_{t}=1$. Capital depreciates at rate $\delta$. To produce one unit of capital in period $t+1$, one unit of goods must be invested in period $t$. Factor markets are competitive and all factors are paid their marginal products. Owners of land and capital earn a fraction $\lambda$ and $\alpha$ of the output, respectively; while labor earns the rest.

The pre-industrial economy contains two groups, nobles and masses, plus the crown. The nobles own the land and the capital stock. They save a fraction $\beta$ of their income each period and invest it. The masses own the labor, and they do not save. The crown fights foreign wars that cost a fraction $x$ of output. We model this cost as pure waste. In the pre-industrial industrial economy, the crown finances the cost of war with a proportional tax on production which reduces the income of all factors by a fraction $x$.

With this simple set of assumptions, we can trace the dynamics of the capital stock in the pre-industrial economy:

$$
k_{t+1}=(1-\delta) \cdot k_{t}+\beta \cdot(\lambda+\alpha) \cdot(1-x) \cdot k_{t}^{\alpha}
$$

Equation (3.2) describes the dynamics of the pre-industrial economy. These dynamics follow the law of motion of the classic Solow model with an investment rate 
equal to $\beta \cdot(\lambda+\alpha) \cdot(1-x)$. From any starting capital stock, the pre-industrial economy converges monotonically to a steady state with the following capital stock:

$$
k^{*}=\left[\frac{\beta \cdot(\lambda+\alpha) \cdot(1-x)}{\delta}\right]^{\frac{1}{1-\alpha}}
$$

We take the steady state of the pre-industrial economy as the starting point of our story. From here, we analyze the consequences of two major developments. The first one is the Industrial Revolution which we interpret as the arrival of a new class of capitalists that brought many important inventions and innovations that radically transformed the British economy. The second development is the Glorious Revolution that converted Britain into a credible borrower and allowed the crown to finance foreign wars through debt accumulation rather than taxes. We study each of these developments in turn.

3.2. A stylized model of the Industrial Revolution. Assume now the arrival of a new class of capitalists with a new industrial technology and an arbitrarily small initial stock of capital. Like the nobles, capitalists save a fraction $\beta$ of their income and invest it. But their technology is $\pi>1$ times more efficient than that of the nobles. That is, for each unit of goods they invest, they obtain $\pi$ units of capital while the nobles obtain only only one unit.

A reasonable-looking but untrue story for the Industrial Revolution would go as follows. The capitalists had great investment opportunities, while the nobles had plenty of savings. This situation led to the rapid development of a private credit market where capitalists heavily borrowed from nobles. Competition for funds equalized the interest rate to the return to the capitalists' investments. In terms of our stylized model, the Industrial Revolution transforms the dynamics of accumulation as follows:

$$
\begin{gathered}
k_{t+1}=(1-\delta) \cdot k_{t}+\pi \cdot \beta \cdot(\lambda+\alpha) \cdot(1-x) \cdot k_{t}^{\alpha} \\
s_{t+1}=\frac{(1-\delta) \cdot k_{t}+\pi \cdot \beta \cdot \alpha \cdot(1-x) \cdot k_{t}^{\alpha}}{(1-\delta) \cdot k_{t}+\pi \cdot \beta \cdot(\lambda+\alpha) \cdot(1-x) \cdot k_{t}^{\alpha}} \cdot s_{t}
\end{gathered}
$$

where $s_{t}$ is the share of the capital stock owned by capitalists. Since the capitalists save the same fraction of their income as the nobles, the aggregate investment rate is not affected by the Industrial Revolution. But Equation (3.4) shows that investment efficiency is now higher since each unit of goods invested produces $\pi$ units of capital rather than one. Equation (3.5) shows how the share of the capital stock owned by the capitalists evolves over time. To understand this Equation, note that the investment that capitalists finance capitalists finance in period $t$ is $\beta \cdot \alpha \cdot s_{t} \cdot(1-x) \cdot k_{t}^{\alpha}$, while total investment is $\beta \cdot(\lambda+\alpha) \cdot(1-x) \cdot k_{t}^{\alpha}$. From any starting capital stock, the industrial economy converges to the following steady state:

$$
k^{*}=\left[\frac{\pi \cdot \beta \cdot(\lambda+\alpha) \cdot(1-x)}{\delta}\right]^{\frac{1}{1-\alpha}} \text { and } s^{*}=0
$$



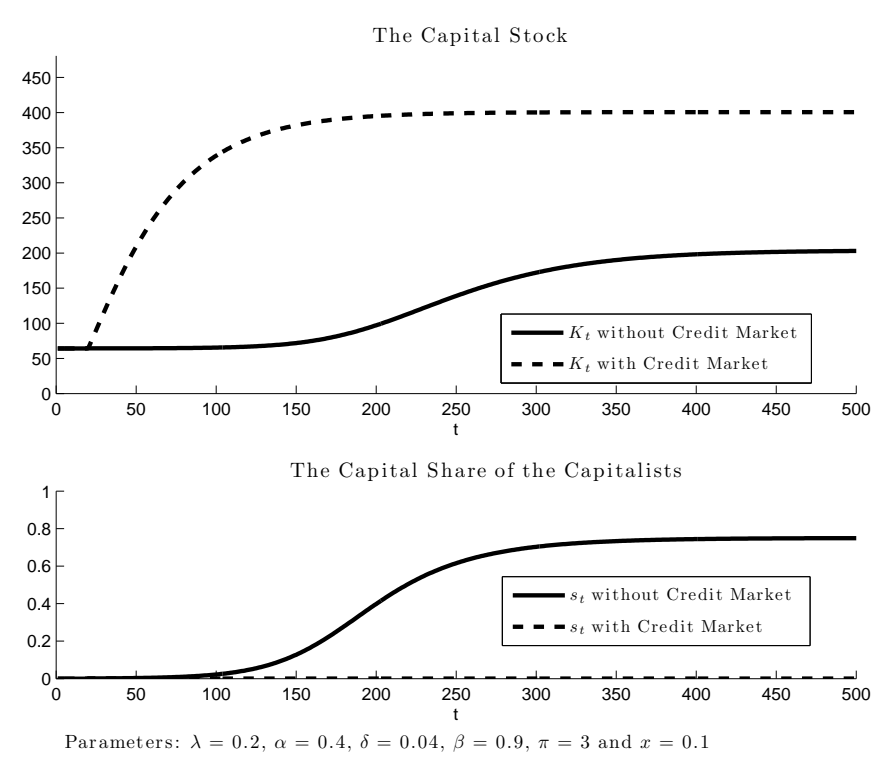

Figure 3.1. Transition to the industrial steady-state with and without credit market

The transition from the pre-industrial steady state in Equation (3.3) to the industrial steady state in Equation (3.6) is shown in Figure 3.1 and 3.2 with dashed lines. The arrival of the capitalists starts a process of fast economic growth as the economy converges to a higher steady-state capital stock. This raises the consumption of both nobles and the masses, but not the consumption of the capitalists. Since competition equalizes the interest rate to the return to investment, the gains from the new technology are reaped by the nobles that finance it and not by the capitalists that own it. Indeed, the capitalists not only do not become rich as a group but their small initial share in the capital stock declines over time and vanishes in the steady state.

This story is straightforward, but it is at odds with what we know about the period. The first problem is that economic growth during the Industrial Revolution was anything but fast. The new industrial technology spread slowly throughout the economy, and it co-existed for a long time with the pre-industrial technology. The second problem is that the nobles did not benefit much from the Industrial Revolution. To the contrary, they found themselves slowly being replaced by the capitalists as the dominant group. The third problem is that wages remained constant or even declined throughout most of the period. It took a long time for the Industrial Revolution to raise the standard of living of the masses.

Let us start our story of the Industrial Revolution again, and let us assume this time that there is no private credit market due to some unspecified friction. In this case, the Industrial Revolution transforms the dynamics of accumulation as follows:

$$
k_{t+1}=(1-\delta) \cdot k_{t}+\beta \cdot\left[\lambda+\alpha \cdot\left(1+(\pi-1) \cdot s_{t}\right)\right] \cdot(1-x) \cdot k_{t}^{\alpha}
$$



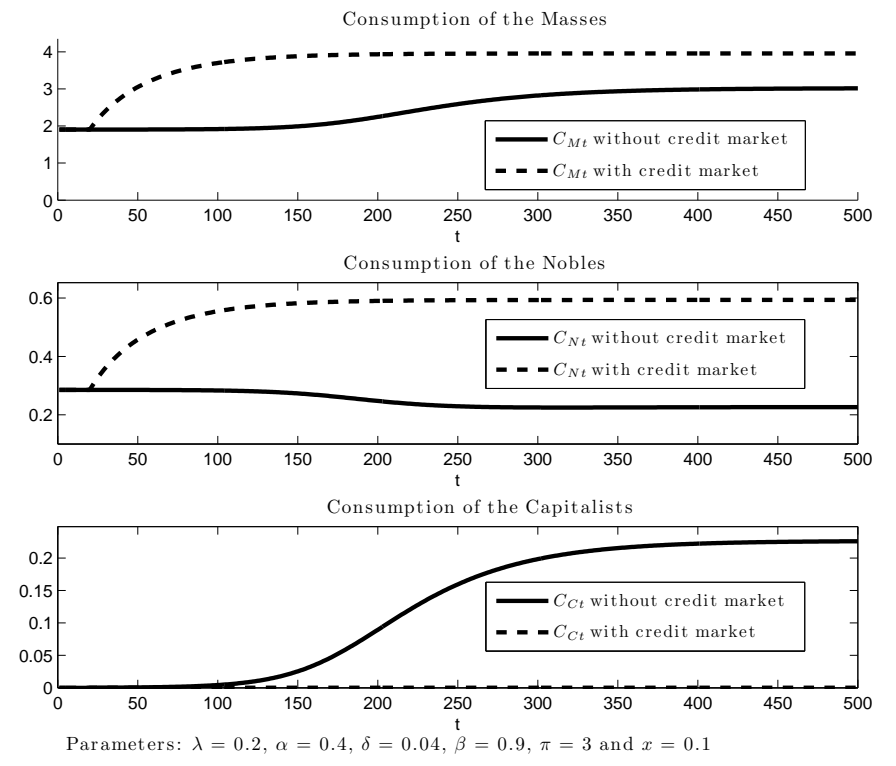

Figure 3.2. Consumption of the three different classes with and without credit market

$$
s_{t+1}=\frac{(1-\delta) \cdot k_{t}+\pi \cdot \beta \cdot \alpha \cdot(1-x) \cdot k_{t}^{\alpha}}{(1-\delta) \cdot k_{t}+\beta \cdot\left[\lambda+\alpha \cdot\left(1+(\pi-1) \cdot s_{t}\right)\right] \cdot(1-x) \cdot k_{t}^{\alpha}} \cdot s_{t}
$$

A comparison of Equations (3.4)-(3.5) and (3.7)-(3.8) shows how the absence of credit and equity markets hampers economic growth. Now it is only the savings of capitalists, i.e. $\beta \cdot \alpha \cdot s_{t} \cdot(1-x) \cdot k_{t}^{\alpha}$; that are invested with the new industrial technology with efficiency $\pi$. The savings of nobles, i.e. $\beta \cdot\left[\lambda+\alpha \cdot\left(1-s_{t}\right)\right]$. $(1-x) \cdot k_{t}^{\alpha}$; are still invested with the old pre-industrial technology. The Industrial Revolution starts slowly since capitalists only have a small amount of initial capital. The ultimate success of the Industrial Revolution depends on whether the share of capital owned by capitalists grows over time. A brief analysis of Equation (3.8) shows that this is the case if and only if the industrial technology is productive enough: $\pi>1+\frac{\lambda}{\alpha}$. We assume this from now on. From any starting capital stock, the industrial economy converges to the following steady state:

$$
k^{*}=\left[\frac{\pi \cdot \beta \cdot \alpha \cdot(1-x)}{\delta}\right]^{\frac{1}{1-\alpha}} \text { and } s^{*}=1-\frac{\lambda}{\alpha \cdot(\pi-1)}
$$

The transition from the pre-industrial steady state in Equation (3.3) to the industrial steady state in Equation (3.9) is shown in 3.1 and 3.2with solid lines. By comparing dashed and solid lines we can determine the consequences of not having a private credit market.

Without a credit market, the Industrial Revolution takes place slowly and leads to a lower steady state capital stock. Interestingly, it now leads to social change as the share of capital owned by capitalists slowly grows from negligible to $s^{*}$. Both observations are related since the implementation of the new technology is only possible as the income share of capitalists grows. Economic growth is slow 
due to a misallocation of investment that declines slowly over time and never quite disappears. That is, economic growth is slow because it requires social change and the latter happens only slowly.

The absence of a private credit market hurts the nobles and the masses. Both groups consume less because capital accumulation slows down. But the nobles are further hurt because they cannot appropriate the gains from the new technology, and this reduces their share of this reduced income. The key beneficiaries of the absence of a private credit market are the capitalists. With a well-functioning private credit market, they would have been condemned to a marginal role as the gains from their technology would have been passed on to the nobles. Without a well-functioning credit market, overall growth is initially slower, but the capitalists keep these gains and their income share increases.

3.3. The role of sovereign debt. Assume now that the arrival of the capitalists coincides with a shift from taxes to debt. Although the cost of foreign wars remains a fraction $x$ of output, the crown no longer needs to finance this cost entirely through taxes as it can issue debt:

$$
d_{t+1}=R_{t} \cdot d_{t}+(x-\tau) \cdot k_{t}^{\alpha}
$$

where $d_{t}$ are the funds raised by issuing debt in period $t-1, R_{t}$ is the gross interest rate paid on this debt and $\tau$ is taxes as a share of output. Equation (3.10) simply says that the crown issues new debt to cover interest payments on existing debt plus the costs of foreign wars minus taxes.

If the debt issued does not exceed the savings of the nobles, the crown must pay an interest rate that equals the return to the investment of nobles:

$$
R_{t}=(1-\tau) \cdot \alpha \cdot k_{t}^{\alpha-1}+1-\delta
$$

At this interest rate, nobles are willing to purchase the crown's debt. But capitalists are not willing to do this since the return to their investments is higher: $\pi \cdot(1-\tau)$. $\alpha \cdot k_{t}^{\alpha-1}+1-\delta>R_{t}$.

For the debt policy described in Equations (3.10) and (3.11) to be feasible, two assumptions are needed. The first one is that debt dynamics be positive so that taxes need not be raised to pay for the debt. This requires that $\pi \cdot \beta>1$. The second assumption is that the total amount of debt never exceeds the wealth of the nobles. This requires that $\frac{x-\tau}{1-\tau}<\frac{\lambda}{1+\frac{\pi \cdot(1-\beta)}{\delta \cdot(\pi \cdot \beta-1)}}$. These two assumptions are consistent with the evidence presented in section II, and we keep them in what follows. Thus, we can now write the dynamics of the industrial economy as follows:

$$
k_{t+1}=(1-\delta) \cdot k_{t}+\beta \cdot\left\{\left[\lambda+\alpha \cdot\left(1+(\pi-1) \cdot s_{t}\right)\right] \cdot(1-\tau) \cdot k_{t}^{\alpha}+R_{t} \cdot d_{t}\right\}-d_{t+1}
$$

$$
s_{t+1}=\frac{(1-\delta) \cdot k_{t}+\pi \cdot \beta \cdot \alpha \cdot(1-\tau) \cdot k_{t}^{\alpha}}{(1-\delta) \cdot k_{t}+\beta \cdot\left\{\left[\lambda+\alpha \cdot\left(1+(\pi-1) \cdot s_{t}\right)\right] \cdot(1-\tau) \cdot k_{t}^{\alpha}+R_{t} \cdot d_{t}\right\}-d_{t+1}} \cdot s_{t}
$$



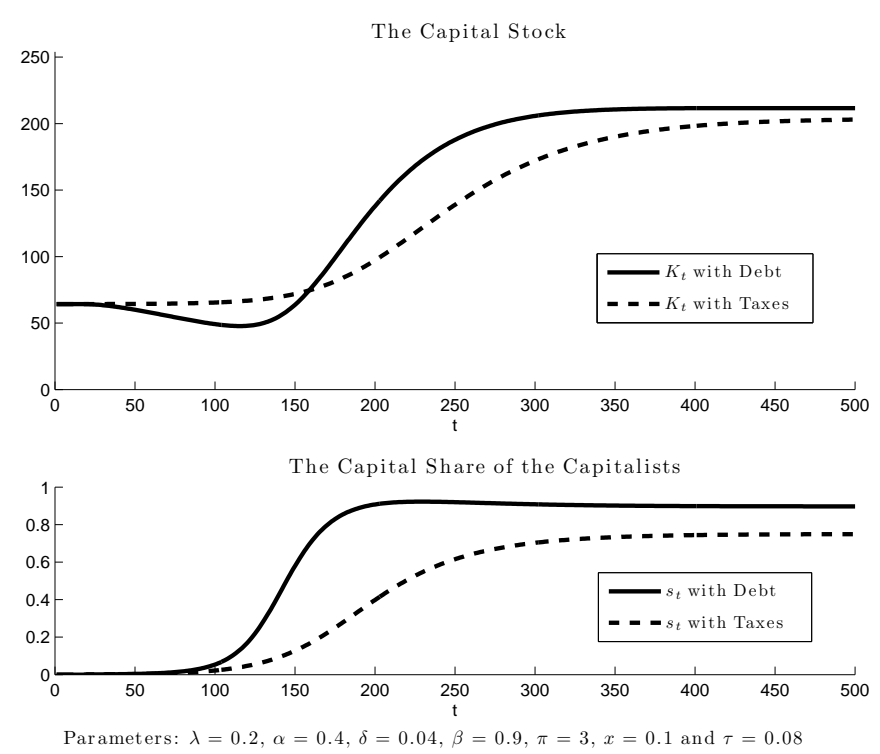

FiguRE 3.3. Transition to the industrial steady-state with debt and taxes

Equation (3.12) shows that, for a given share of the capital stock owned by capitalists, debt slows down capital accumulation. The reason is that sovereign debt crowds out investment by the nobles. In particular, their investment declines by $d_{t+1}-\beta \cdot R_{t} \cdot d_{t}$. But Equation (3.13) also shows that debt increases the share of capital owned by capitalists. From any starting capital stock, the industrial economy converges to the following steady state:

$$
k^{*}=\left[\frac{\pi \cdot \beta \cdot \alpha \cdot(1-\tau)}{\delta}\right]^{\frac{1}{1-\alpha}} \text { and } s^{*}=1-\frac{\lambda-\frac{x-\tau}{1-\tau} \cdot\left[1+\frac{\pi \cdot(1-\beta)}{\delta \cdot(\pi \cdot \beta-1)}\right]}{\alpha \cdot(\pi-1)}
$$

The transition from the pre-industrial steady state in Equation (3.3) to the industrial steady state in Equation (3.14) is shown in Figures 3.3 and 3.4 with solid lines. By comparing dashed and solid lines we see the effects of sovereign debt.

The shift to debt financing initially slows down growth and eventually increases it, leading the economy to a steady state with a higher capital stock. To understand this result, note that sovereign debt has two countervailing effects on capital accumulation. The first one is a crowding-out effect. Sovereign debt reduces the investments of the nobles and this initially lowers the capital stock. The second one however is a crowding-in effect. As the capital stock declines, wages and land rentals fall and the return to the investments of capitalists increase. Both effects accelerate social change but they have contrasting effects on growth. The crowdingout effect is static and works on impact, while the crowding-in effect is dynamic and works over time. Hence, debt accumulation initially slows down growth but then it accelerates it and raises the capital stock permanently. Crucial for this latter result is that debt dynamics are positive and the crown does not need to raise surpluses in order to pay the debt. 

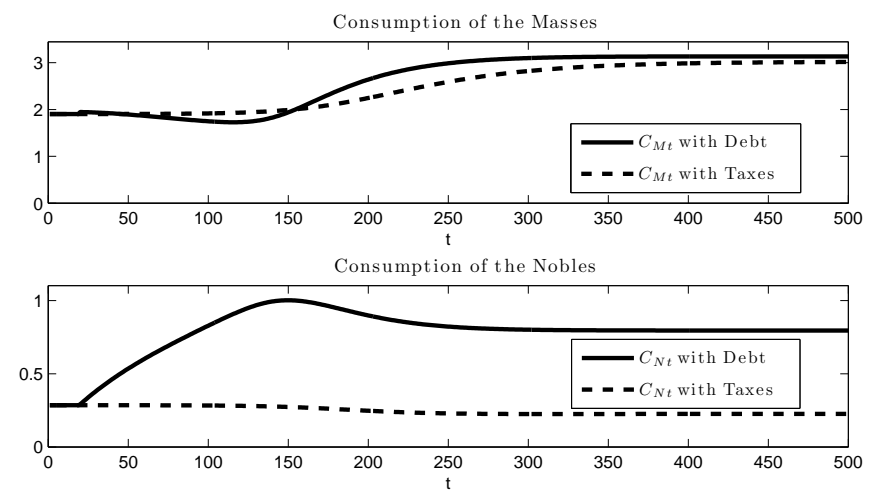

Consumption of the Capitalists

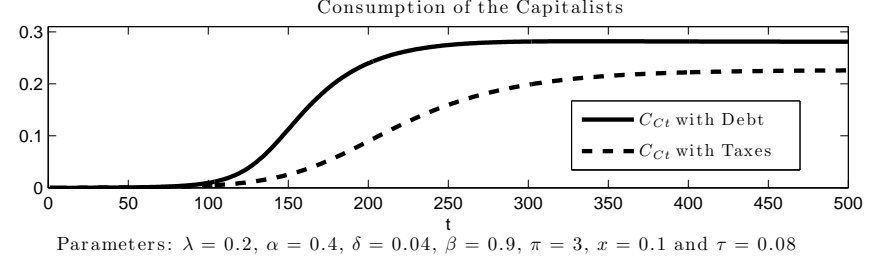

Figure 3.4. Consumption of the three different classes with debt and taxes

The shift from taxes to debt raises the consumption of all groups. One reason, of course, is that taxes decline for all groups. Initially, the masses and the nobles find that this effect is offset by lower wages and land rentals as the capital stock declines, but eventually both wages and land rentals increase and the capital stock increases. The consumption of nobles and capitalists is also affected because the return to their investments increases initially, although it then declines as the capital stock grows and the economy reaches the steady state. The observation that debt raises consumption should not be surprising since positive debt dynamics are possible if and only if the investments of the nobles are dynamically inefficient. It is well-known that, in this situation, it is possible to increase consumption by lowering these investments. What is interesting here is that this effect is reinforced because debt indirectly increases the investments of capitalists which are dynamically efficient.

3.4. A simple numerical exploration. A serious quantitative assessment of the effects of 18th century British debt accumulation requires reasonably precise estimates of a large number of model parameters. Despite some successful attempts in recent years (Stokey 2001, Crafts and Harley 2000), we refrain from a full-scale calibration of our model. However, to demonstrate the magnitude of effects in an approximate fashion, we perform a crude numerical simulation of the model.

To do this, we use parameter values that allow us to interpret one period in the model as one year. First, we assign factor shares: we set the land share $\lambda=0.2$ and the capital share $\alpha=0.4$. These numbers are consistent with the evidence presented in section 2, and are broadly in line with factor shares used in growth accounting exercises (Antras and Voth 2003, Crafts and Harley 1992). Second, we set the depreciation rate $\delta=0.04$, which is a standard number in this sort of 
exercises. Third, we set the relative efficiency of investment in the new sectors $\pi=3$. This choice for $\pi$ implies that the Industrial Revolution raises steady-state per capita income by a factor of 1.6. Fourth, we use $\beta=0.9$. Having a high value for $\beta$ is necessary to create the savings that simultaneously financed the Industrial Revolution and massive debt accumulation - a key feature of the economic and financial history of the period (Neal 1993). Finally, we assume the initial share of the capital stock owned by capitalists is 0.001 , that inital debt is zero, and that the initial capital stock is at the steady state of the pre-industrial society.

We consider three scenarios. In all of them, we set $x=0.132$. This corresponds to the historical average spending for the period 1700-1850. In the first scenario, we use $\tau=0.108$ which is also the historical average taxes for the same period. Thus, this scenario assumes an annual government deficit of $2.4 \%$ that is financed by issuing debt. We refer to this scenario as the baseline scenario. We then construct two scenarios in which we set $\tau=0.120$ and $\tau=0.132$, respectively. Thus, in these counterfactuals the government deficit is reduced to $1.2 \%$ and $0 \%$ per annum. ${ }^{15}$

Figure 3.5 depicts the evolution of the debt-income ratio under these scenarios. In the baseline case, the debt-income ratio grows quickly reaching a peak of 2.28. This happens 114 periods after the start of the Industrial Revolution. After this, the debt-income ratio declines steadily and stabilizes around 0.95. In the counterfactual with a $1.2 \%$ deficit, the debt-income ratio follows a similar path although its absolute value is about half. The peak of 0.94 now occurs 127 periods after the Industrial Revolution starts. The debt-income ratio steadily declines afterwards; it stabilizes at 0.48 . Of course, in the conterfactual scenario with zero deficit, the debt-income ratio remains at zero throughout.

Figure 3.6 shows the implications of these scenarios for the share of capital owned by capitalists. In the baseline scenario, we find that the share of the capital stock owned by capitalists grows quickly and, 114 periods after the start of the Industrial Revolution, it reaches a value of $50 \%$. This capitalist "takeover" is essentially complete by period 125 when this share surpasses $70 \%$. Rapid social change is indeed one of the main effects of the massive buildup of debt after 1700. As the nobles embark on large debt purchases, their investments decline and so do wages. This raises the profits of capitalists who efficiently reinvested them and quickly became rich. The importance of sovereign debt in this process can be seen by looking at the two counterfactual scenarios. In them, we find that 114 periods after the start of the Industrial Revolution, the share of capital owned by capitalists is only $18 \%$ and $7.5 \%$; and it takes 177 and 278 periods for this share to reach $70 \%$.

Figure 3.7 displays the combined effects of the debt buildup on per capita income (or wages, since these are a fixed fraction of per capita income). The first one is the crowding-out effect that happens on impact: the higher the debt, the larger the fall

\footnotetext{
${ }^{15}$ We constructed Figures 9 and 10 using the same set of parameters. Thus, the reader can go back to them to see what the baseline and the $0 \%$ deficit scenarios imply for the capital stock and the consumptions of the different groups.
} 


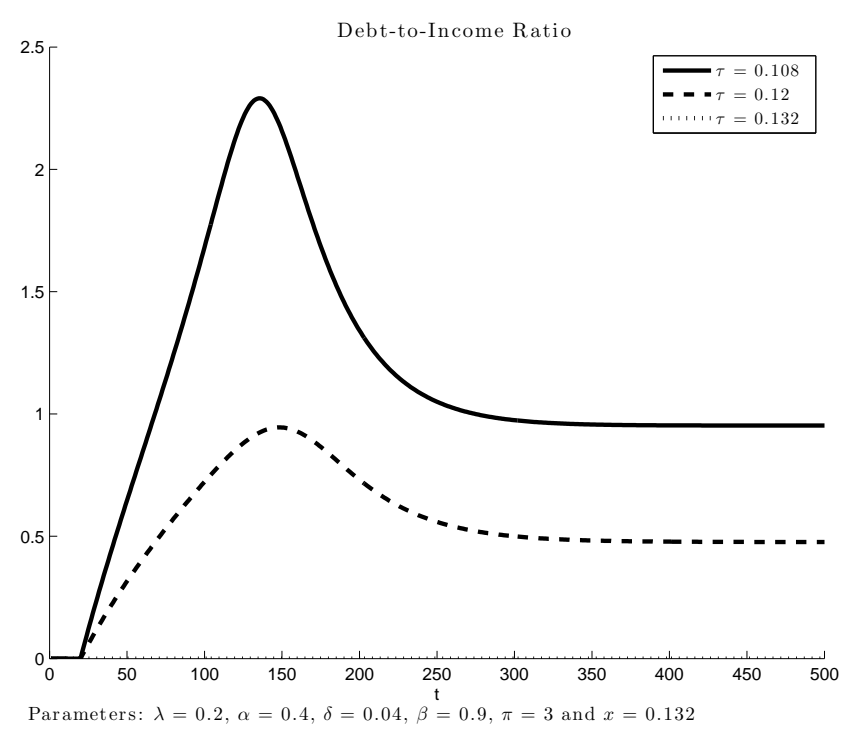

FiguRE 3.5. Debt-to-income ratio under different scenarios

in investment, driven by the fact that the nobility reduces its own low-productivity investments. The second effect is the crowding-in that happens gradually: the higher the debt, the faster is social change and the larger the growth of highproductivity investments by the capitalists eventually. In the baseline scenario, the dynamic interplay of these two effects implies that the Industrial Revolution is initially slow as the crowding-out effect dominates; thereafter growth accelerates as the crowding-in effect becomes large. Thus, income falls by almost $15 \%$ during the first 99 periods only to rebound quickly. Indeed, by period 171 the economy has already traveled $50 \%$ of the distance between the pre- and post-industrial steady states. And in period 200 it has traveled $75 \%$ of this distance.

Once again, the importance of debt accumulation in shaping income dynamics can be appreciated by comparing the baseline scenario with the two counterfactuals. In the counterfactual with a $0 \%$ deficit, none of the two effects are present. As a result, the Industrial Revolution leads to a very slow transition between steady states. There is no decline in income in the first 99 periods as in the baseline scenario, but it then takes 225 periods to travel half the distance between the preand post-industrial steady states, and 274 periods to travel $75 \%$ percent of the distance. Not surprisingly, the counterfactual scenario with $1.2 \%$ deficit shows income dynamics that are somewhat in between those of the baseline and $0 \%$ deficit scenarios. In this case income falls by $6.5 \%$ from the start of the Industrial Revolution to period 99, and it then starts to grow. In this scenario, it takes 196 and 234 periods to cover $50 \%$ and $75 \%$ of the distance between steady states, respectively. In other words, the higher debt accumulation, the greater the initial dip in incomes, and the faster growth as well as structural and social change become. 


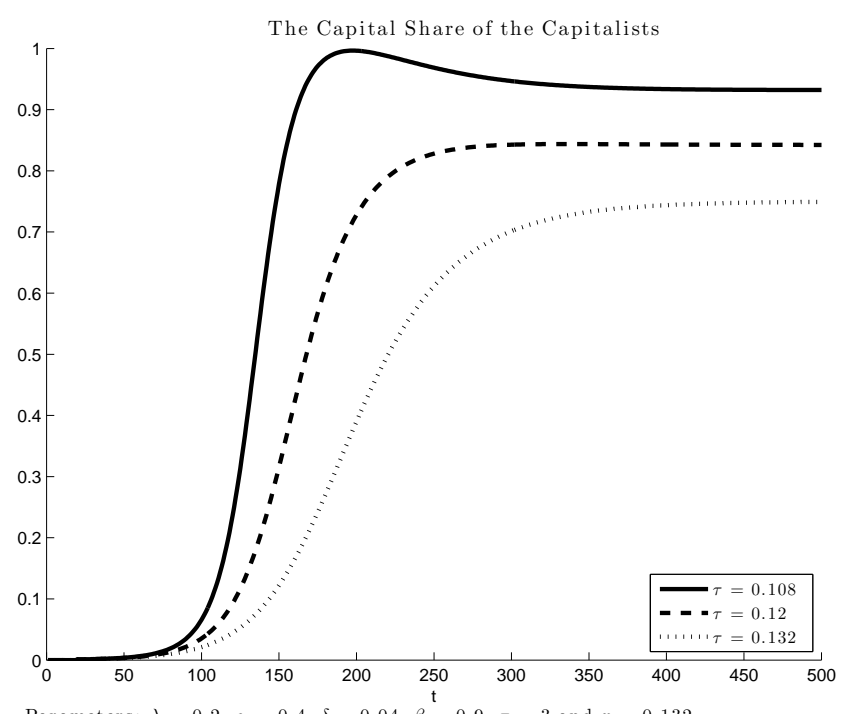

FigurE 3.6. Capital share of the capitalists under different scenarios

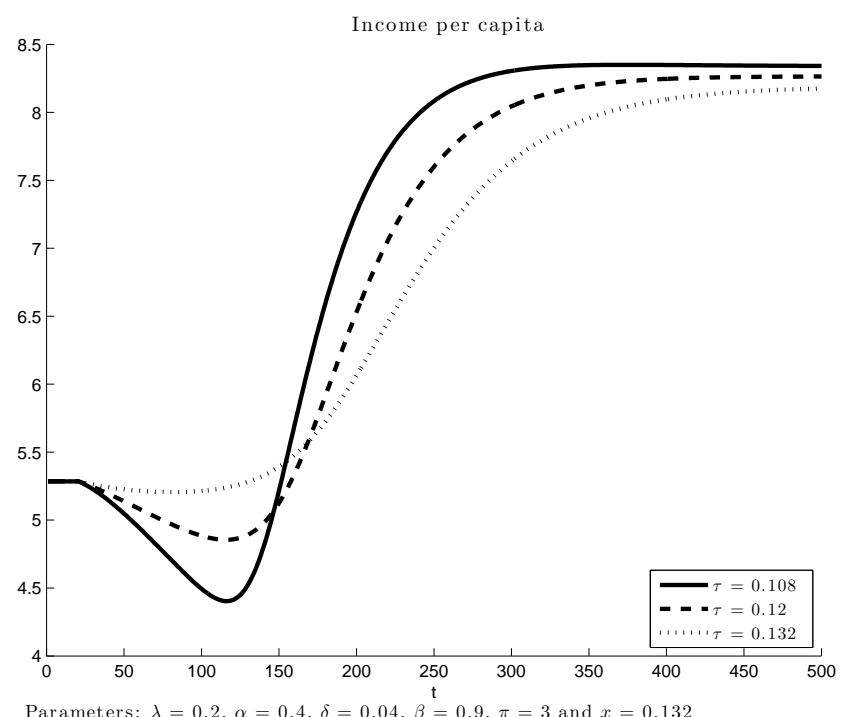

FiguRE 3.7. Income per capita under different scenarios

3.5. Discussion. The crude numerical simulation in section 3.4 is not designed to match all the different aspects of Britain's historical growth experience. However, it sheds light on a number of important features. There is growing evidence that wage and output growth were indeed slow, as our model predicts for the initial phase of debt accumulation (Crafts and Harley 1992, Feinstein 1998). However, wages and output per capita probably did not fall in absolute terms, at least for extended periods of time, in contrast to our model's prediction. Adding an additional, broader productivity trend for the entire economy to our simulation would 
"fix" this problem; but since we mainly aim at clarifying magnitudes, rather than maximizing fit, we abstain from such a modification.

Similarly, factor shares probably shifted during the British IR - Allen's work (Allen 2009b) strongly suggests that, as population surged, the share of national income going to labor declined, while profits in the new sectors were sky-high. To keep our exposition simple, we do not include specifications with shifting factor shares; we note in passing that the extremely high rates of profit in new industries are a clear sign of misallocation - namely a failure to redeploy more capital in the sectors that used it most efficiently, driven by the shortcomings of Britain's financial system (Banerjee and Munshi 2004).

Finally, we note some limitations of our argument. Undoubtedly, the first-best for industrializing Britain would have been a financial system that quickly and cheaply transferred capital from agriculture to the new industries. Growth would have been fastest in this case. Given that financial intermediation was stifled by government intervention, the issuance of debt created a second-best solution - it allowed for a transfer of resources from "old" to "new" industries through linkages in factor markets. The same appliesto the case of war. Without expensive wars and the debt that they required, growth would have been slower - but if an efficient financial system had allowed for the transfer of resources directly, Britain could have grown even faster, and without a "need" for numerous expensive military conflicts. In other words, it was a particular confluence of factors that allowed Britain to pile up debt at a high rate, creating the largest (sustainable) debt mountain in history, while industrializing at the same time: Given the limitations of its financial system, war helped to mitigate the consequences of inefficient capital allocation by crowding out inefficient investment.

\section{Concluding Remarks}

Under what conditions is debt growth-enhancing? Reinhart and Rogoff (2009) famously argue that major sovereign debt accumulation tends to be associated with low growth. But not all debt accumulation episodes are similar. What makes this 18th century British episode special is the role of debt as a store of value. In the absence of a well-developed private credit market, the appearance of a new store of value displaced low-productivity investments and released resources that were used to finance high-productivity investments. Are there other situations where such a mechanism might be at work?

We can think at least of two such scenarios. The financial crisis of 2007-08 and the long expansion that preceded it have been interpreted by many as the result of an asset bubble popping-up and bursting. Just like sovereign debt, asset bubbles are stores of value. In a similar spirit to ours, a number of recent studies have focused on how asset bubbles can overcome financial frictions and enhance growth (Caballero and Krishnamurty 2006 , Farhi and Tirole 2014, Martin and Ventura 
2014). ${ }^{16}$ Since 21st century United States and Europe possess developed financial markets, this research has emphasized liquidity or collateral, factors that are less likely to have played the main role in 18th century Britain.

Factors what we highlight for the case of Britain may also have contributed to China's spectacular rise in recent decades. Song, Storesletten and Zilibotti (2011) argue that Chinese growth is driven by the transfer of resources from lowproductivity state firms to high-productivity private firms - severe financial frictions stop private firms from borrowing and force them to finance their investments through retained earnings. In such a setting, China's foreign reserve accumulation may have played a role similar to the buying of government debt by the British nobility: Reduced investments by state firms might have lowered the demand for labor and wages, raising the profits of private firms and leading to faster growth and more rapid structural change.

\section{REFERENCES}

Abel, A. B., N. G. Mankiw, L. H. Summers, and R. J. Zeckhauser (1989): "Assessing Dynamic Efficiency: Theory and Evidence," The Review of Economic Studies, 56(1), 1-19.

Allen, R. C. (1999): "Tracking the Agricultural Revolution in England," The Economic History Review, 52(2), pp. 209-235.

(2009a): The British Industrial Revolution in Global Perspective. Cambridge University Press.

- (2009b): "Engels' Pause: Technical Change, Capital Accumulation, and Inequality in the British Industrial Revolution," Explorations in Economic History, 46(4), $418-435$.

Antras, P., And H.-J. Voth (2003): "Factor Prices and Productivity Growth during the British Industrial Revolution," Explorations in Economic History, $40(1), 52-77$.

Ashton, T. S. (1948): The Industrial Revolution 1760-1830, Volume 204. CUP Archive.

Azam, J. P., B. Biais, M. DiA, and C. Maurel (2001): "Informal and Formal credit markets and credit rationing in Côte d'Ivoire," Oxford Review of Economic Policy, 17(4), 520-534.

Banerjee, A., And K. Munshi (2004): "How efficiently is capital allocated? Evidence from the knitted garment industry in Tirupur," The Review of Economic Studies, 71(1), 19-42.

Banerjee, A. V., And E. Duflo (2005): "Growth theory through the lens of development economics," Handbook of economic growth, 1, 473-552.

\footnotetext{
${ }^{16}$ One exception is Ventura (2012) who shows how asset bubbles reduce the effects of frictions to international capital flows by shifting investments from low- to high-productivity countries. The mechanism has a number of similarities with the one we emphasize here, but it works through the cost of capital rather than through wages.
} 
Banerjee, A. V., And E. Duflo (2014): "Do Firms Want to Borrow More? Testing Credit Constraints Using a Directed Lending Program," The Review of Economic Studies, 81(2), 572-607.

Banerjee, A. V., And B. Moll (2010): "Why Does Misallocation Persist?," American Economic Journal: Macroeconomics, 2(1), 189-206.

BArro, R. J. (1987): "Government Spending, Interest Rates, Prices, and Budget Deficits in the United Kingdom, 1701-1918," Journal of Monetary Economics, $20(2), 221-247$.

Brewer, J. (1990): The Sinews of Power? War, Money and the English State, 1688-1783. Harvard University Press.

Broadberry, S. N., B. M. Campbell, A. D. Klein, M. Overton, and B. V. LEEUWEN (2010): "British Economic Growth: 1270-1870," Warwick wp.

Brunt, L. (2006): "Rediscovering Risk: Country Banks as Venture Capital Firms in the First Industrial Revolution," The Journal of Economic History, 66(01), 74-102.

Caballero, R. J., and A. Krishnamurthy (2006): "Bubbles and Capital Flow Volatility: Causes and Risk management," Journal of Monetary Economics, $53(1), 35-53$.

Clark, G. (1998): "Commons Sense: Common Property Rights, Efficiency, and Institutional Change," The Journal of Economic History, 58(1), pp. 73-102. (2001): "Debt, Deficits, and Crowding Out: England, 1727-1840," European Review of Economic History, 5(03), 403-436.

(2002): "Land Rental Values and the Agrarian Economy: England and Wales, 1500 1914," European Review of Economic History, 6(03), 281-308.

(2005): "The Condition of the Working Class in Egland, 1209-2004," Journal of Political Economy, 113(6), 1307-1340.

CRAfts, N. (1985): British Economic Growth during the Industrial Revolution. Oxford Clarendon Press.

Crafts, N. (2005): "The First Industrial Revolution: Resolving the Slow Growth/Rapid Industrialization Paradox," Journal of the European Economic Assocation, 3(2/3), 525-534.

Crafts, N. F. R., and C. K. Harley (1992): "Output Growth and the British Industrial Revolution: A Restatement of the Crafts-Harley View," The Economic History Review, 45(4), pp. 703-730.

Dickson, P. G. M. (1967): The Financial Revolution in England: A Study in the Development of Public Credit, 1688-1756. Macmillan.

FARhi, E., And J. Tirole (2011): "Bubbly liquidity," The Review of Economic Studies, p. rdr039.

Feinstein, C. H. (1998): "Pessimism Perpetuated: Real Wages and the Standard of Living in Britain during and after the Industrial Revolution," The Journal of Economic History, 58(3), pp. 625-658. 
Galor, O. (2005): "From Stagnation to Growth: Unified Growth Theory," in Handbook of Economic Growth, ed. by P. Aghion, and S. Durlauf, vol. 1 of Handbook of Economic Growth, chap. 4, pp. 171-293. Elsevier.

Gancia, G., and F. Zilibotti (2009): "Technological Change and the Wealth of Nations," Annual Review of Economics, 1(1), 93-120.

HABAKKuK, H. J. (1994): Marriage, Debt, and the Estates System: English Landownership, 1650-1950. Clarendon Press.

Harley, C. K., And N. F. Crafts (2000): "Simulating the Two Views of the British Industrial Revolution," The Journal of Economic History, 60(03), 819841 .

Harris, R. (1994): "The Bubble Act: Its Passage and Its Effects on Business Organization," The Journal of Economic History, 54(3), pp. 610-627.

Heim, C. E., And P. Mirowski (1987): "Interest Rates and Crowding-Out During Britain's Industrial Revolution," The Journal of Economic History, 47, 117-139.

HsieH, C.-T., AND P. J. KLENOW (2009): "Misallocation and Manufacturing TFP in China and India," The Quarterly Journal of Economics, 124(4), 1403-1448.

Lindert, P. H. (1986): "Unequal English Wealth since 1670," Journal of Political Economy, 94(6), pp. 1127-1162.

Martin, A., And J. Ventura (forthcoming): "Managing Credit Bubbles," Journal of the European Economic Association.

MCCloskey, D. N. (1972): "The Enclosure of Open Fields: Preface to a Study of Its Impact on the Efficiency of English Agriculture in the Eighteenth Century," The Journal of Economic History, 32(1), pp. 15-35.

MCCRAw, T. K. (1997): Creating Modern Capitalism: How Entrepreneurs, Companies and Countries Triumphed in Three Industrial Revolutions. Harvard University Press.

Mirowski, P. (1981): "The Rise (and Retreat) of a Market: English Joint Stock Shares in the Eighteenth Century," The Journal of Economic History, 41(3), pp. $559-577$.

MokyR, J. (1999): Editor's Introduction: The New Economic History and The Industrial Revolution. Boulder: Westview Press.

NEAL, L. (1993): The rise of financial capitalism: International capital markets in the age of reason. Cambridge University Press.

North, D. C., And B. R. Weingast (1989): "Constitutions and commitment: the evolution of institutions governing public choice in seventeenth-century England," The journal of economic history, 49(04), 803-832.

Philip Hoffman, G. P.-V., And J.-L. Rosenthal (2000): Priceless Markets: The Political Economy of Credit in Paris, 1660-1870. University of Chicago Press.

Phillips, A. D. M. (1989): The Underdraining of Farmland in England during the Nineteenth Century. Cambridge University Press.

Postan, M. M. (1935): "Recent Trends in the Accumulation of Capital," The Economic History Review, 6(1), pp. 1-12. 
Quinn, S. (2001): “The Glorious Revolution's Effect on English Private Finance: A Microhistory, 1680-1705," The Journal of Economic History, 61(3), pp. 593-615.

Reinhart, C. M., And K. RogofF (2009): This time is different: eight centuries of financial folly. princeton university press.

Rubinstein, W. D. (1977): "Wealth, Elites and the Class Structure of Modern Britain," Past and Present, (76), pp. 99-126.

Song, Z., K. Storesletten, and F. Zilibotti (2011): "Growing Like China," American Economic Review, 101(1), 196-233.

Stokey, N. L. (2001): "A quantitative model of the British industrial revolution, 1780-1850," in Carnegie-Rochester Conference Series on Public Policy, vol. 55, pp. 55-109. Elsevier.

Sussman, N., And Y. YAfeh (2004): "Constitutions and Commitment: Evidence on the Relation Between Institutions and the Cost of Capital," CEPR Discussion Papers 4404, C.E.P.R. Discussion Papers.

(2006): "Institutional reforms, financial development and sovereign debt: Britain 1690-1790," The Journal of Economic History, 66(04), 906-935.

Temin, P. (1997): "Two Views of the British Industrial Revolution," The Journal of Economic History, 57(01), 63-82.

Temin, P., And H.-J. Voth (2008): "Interest Rate Restrictions in a Natural Experiment: Loan Allocation and the Change in the Usury Laws in 1714," The Economic Journal, 118(528), pp. 743-758.

Thompson, F. M. L. (1963): English Landed Society in the Nineteenth Century. London: Routledge and Kegan Paul.

Townsend, R. (2005): "Networks and finance in poor neighborhoods," Credit Markets for the Poor. New York, NY: Russell Sage Foundation.

Ventura, J. (2012): "Bubbles and capital flows," Journal of Economic Theory, $147(2), 738-758$.

Williamson, J. G. (1984): "Why Was British Growth So Slow During the Industrial Revolution?," The Journal of Economic History, 44(3), pp. 687-712.

Wrigley, E. A. (1985): "Urban Growth and Agricultural Change: England and the Continent in the Early Modern Period," The Journal of Interdisciplinary History, 15(4), pp. 683-728. 